Annales Geophysicae (2002) 20: 547-557 (c) European Geophysical Society 2002

\title{
Ozone generation over the Indian Ocean during the South African biomass-burning period: case study of October 1992.
}

\author{
F. G. Taupin ${ }^{1,2}$, M. Beekmann ${ }^{3}$, P. J. Brémaud ${ }^{1}$, and T. Randriambelo ${ }^{1}$ \\ ${ }^{1}$ Laboratoire de physique de l'atmosphère, Université de la Réunion, 97715 Saint-Denis messag cedex 9, France \\ ${ }^{2}$ Now at LPCE-CNRS, 45071 Orléans cedex 2, France \\ ${ }^{3}$ Service d'Aéronomie du CNRS, Université Pierre et Marie Curie, Paris, 75252 Paris Cedex 05, France
}

Received: 23 September 1999 - Revised: 19 July 2001 - Accepted: 29 August 2001

\begin{abstract}
In this study, we present an estimation of photochemical ozone production during free tropospheric transport between the African biomass burning area and Reunion Island (Indian Ocean) by means of trajectory-chemistry model calculations. Indeed, enhanced ozone concentrations ( $80-100 \mathrm{ppbv}$ ) between 5 and $8 \mathrm{~km}$ height over Reunion Island are encountered during September-October when African biomass burning is active. The measurements performed during flight 10 of the TRACE-A campaign (October 6,1992 ) have been used to initialise the lagrangian trajectory-chemistry model and several chemical forward trajectories, which reach the area of Reunion Island some days later, are calculated. We show that the ozone burden already present in the middle and upper troposphere over Southern Africa, formed from biomass burning emissions, is further enhanced by photochemical production over the Indian Ocean at the rate of 2.5-3 ppbv/day. The paper presents sensitivity studies of how these photochemical ozone production rates depend on initial conditions. The rates are also compared to those obtained by other studies over the Atlantic Ocean. The importance of our results for the regional ozone budget over the Indian Ocean is briefly discussed.
\end{abstract}

Key words. Atmospheric composition and structure (evolution of the atmosphere; troposphere - composition and chemistry); meterorology and atmospheric dynamics (tropical meteorology)

\section{Introduction}

Photochemical ozone production, from biomass burning emissions over Africa during the September-November period, affects large parts of the Southern tropical Indian Ocean as can be seen in TOMS/SBUV daily tropospheric ozone maps (Fishman et al., 1996a). Also, ozone concentrations that we currently measure over Reunion Island during the biomass burning season are about $80-100$ ppbv at $5-8 \mathrm{~km}$

Correspondence to: F. G. Taupin (goffinon@cnrs-orleans.fr) height while the background concentrations are about 50$60 \mathrm{ppbv}$ (Taupin et al., 1999). Backtrajectory analyses from locations of enhanced ozone concentrations have shown an origin over southeastern Africa and Madagascar (Baldy et al., 1996; Diab et al., 1996). The forward trajectory analyses of Thompson et al. (1996) from fire locations in southern Africa showed that Reunion Island was within the sphere of influence of southern African biomass burning products. For the period of the TRACE-A campaign (September-October 1992), Garstang et al. (1996) have shown that, south of $18^{\circ} \mathrm{S}$, the easterly transport mode out to the Indian Ocean comprised $90 \%$ of the transport pathways compared with only $4 \%$ out to the west. More recently, Randriambelo et al. (2000) presented a detailed climatological investigation of 7 years (1992-1999) of 2-monthly PTU-O 3 radiosondes. The ozone contamination from biomass burning was shown to be maximum over Reunion Island during October. However, it is not clear (Baldy et al., 1996) whether the ozone build-up is confined to a region near emission sources, with subsequent transport to Reunion Island (Cook-then-Mix), or whether photochemical ozone production is still active over the Indian Ocean (Mix-then-Cook). Therefore, in the present study, we wish to perform trajectory-chemistry modelling in order:

1. to explain the possible photochemical origin of ozone enriched layers observed at Reunion Island and

2. to test, respectively, the validity of the Mix-then-Cook or Cook-then-Mix hypotheses.

The TRACE-A (Transport and Atmospheric Chemistry near the Equator-Atlantic) campaign was conducted in October 1992, to study the source and transport of primary and secondary ozone precursors associated with biomass burning in South America and Southern Africa. The measurements conducted during this campaign have shown that the presence of widespread biomass burning, in both South America and southern Africa, is a primary driver of the "global smog" phenomenon observed in the southern tropics. How- 


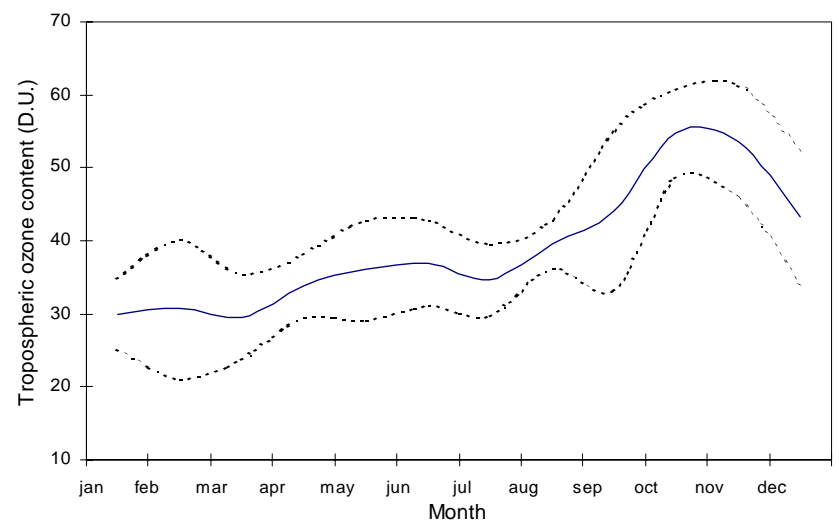

Fig. 1. Seasonal variation of monthly averaged integrated ozone content (thick line) between the ground and the tropopause. The standard deviation calculated from all the 73 profiles is also represented as dashed lines.

ever, the presence of biomass burning is not sufficient to generate the ozone maximum observed far away from the trace gas source; relatively small scale convective processes occurring on each continent collectively become a necessary contributor to the large-scale observed ozone enhancement (Fishman et al., 1996b).

In this paper, we present a case study of the quantification of the ozone generation during the free tropospheric transport between the African biomass burning area and the Indian Ocean, in order to further explain enhanced ozone data observed at Reunion Island which are presented in Sect. 2.1. The simulations have been conducted by using a simple trajectory-chemistry model that we initialise with airborne trace gas measurements made during the TRACE-A experiment conducted in October 1992 over Africa (Fishman et al., 1996b) and presented in Sect. 2.2. The meteorological context of the case study is outlined briefly in Sect. 3. The model is described in Sect. 4. In Sect. 5, the net ozone production between Africa and Reunion Island is calculated and compared to results from other studies. The relevance of the results obtained for larger scale ozone formation from biomass burning and its transport over the Indian Ocean is then discussed.

\section{Experimental data and eastward transport from the African continent}

\subsection{Tropospheric ozone above Reunion Island}

The monthly average from 1992 to 1997 of the seasonal variation of column-integrated tropospheric ozone is presented in Fig. 1 (Taupin, 1998; Taupin et al., 1999). The high amplitude of the seasonal variation (25 DU; one Dobson unit equals $2.6 * 10^{16}$ molecules $/ \mathrm{cm}^{2}$ ) is due primarily to the high peak (55DU) appearing in October. Several significant influences on ozone concentration above the south-western Indian Ocean have been highlighted and qualitatively demonstrated,

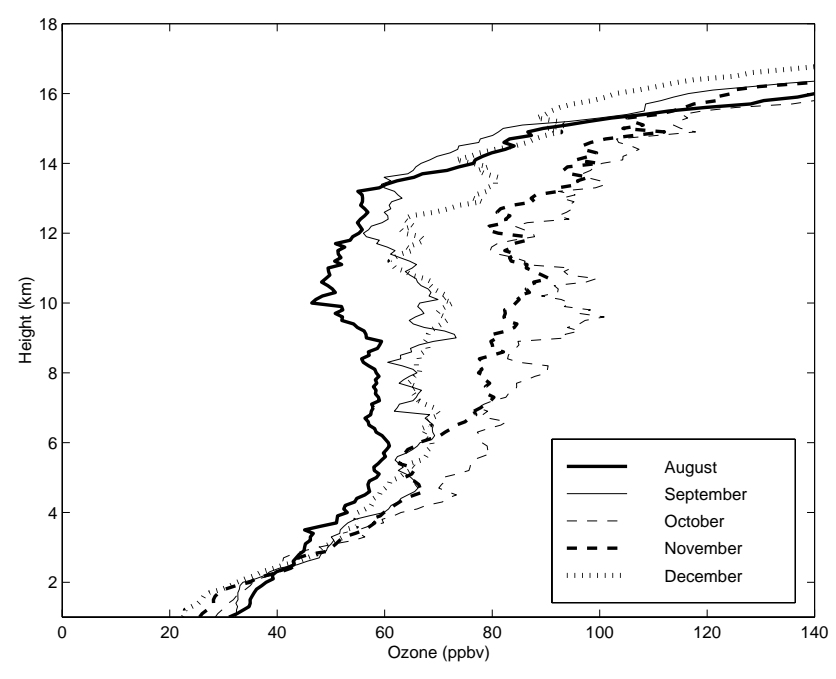

Fig. 2. Mean monthly tropospheric ozone profiles obtained by radiosondes at Reunion Island from August to December (Randriambelo et al., 2000).

namely transport from the stratosphere (Baray et al., 1998), and photochemical formation from biomass burning emissions (Taupin et al., 1999; Randriambelo et al., 2000). In the study of Randriambelo et al. (2000), recent stratospheric intrusions have been eliminated from the ozone climatology using an identification method based on considerations of ozone, humidity, vertical stability and meteorological conditions. Figure 2, extracted from Randriambelo et al. (2000), presents averaged monthly tropospheric ozone profiles obtained by radiosondes at Reunion from August to December 1992 to 1998; these are considered to be representative from the biomass burning source. It clearly shows a maximum of ozone appearing in October that can be explained by the presence of intense fires and of deep convective clouds both in the south-eastern African continent and Madagascar.

In this study, we will focus on the ozone measurements performed at Reunion Island during the same period as three flights of the TRACE-A campaign on the African continent. Indeed, the large number of species measured during this campaign can provide a unique opportunity to best constrain the initial conditions for modelling the ozone formation during transport from the African continent to the Indian Ocean. Two Reunion Island measurement dates are concerned, the 6 and 13 October 1992. The Fig. 3 presents the vertical profiles of relative humidity, temperature and ozone mixing ratio recorded from the surface to $12 \mathrm{~km}(1000 \mathrm{to} 150 \mathrm{hPa})$ for these two dates.

Regarding the temperature, several thermal inversions can be visually identified in each case. Between each thermal inversion stable layers are capped that correspond to a strong relative humidity decrease and ozone enhancement. The first inversion is localized between 800 and $700 \mathrm{hPa}$ depending on the case study. This corresponds to the well-known tradeinversion (Taupin et al., 1999). The ozone enhancement observed in this stable layer is 10 to $30 \mathrm{ppbv}$. Above $700 \mathrm{hPa}$, 

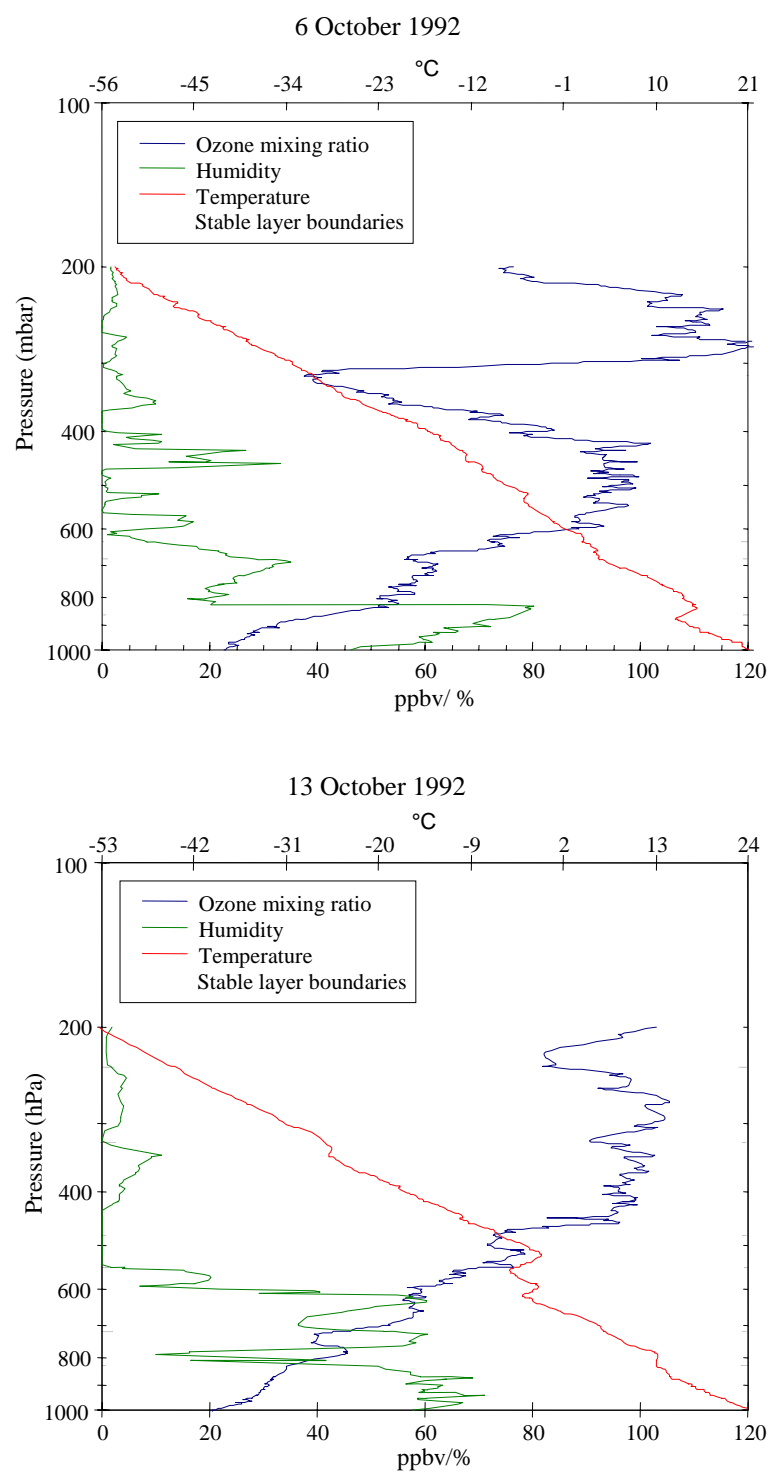

Fig. 3. Altitude profiles of temperature, relative humidity, and ozone mixing ratio measured at Reunion Island for two dates: 6 October (a), and 13 October (b), 1992.

each case study differentiates by the number of stable layers. Concerning the 6 October profiles, one large contaminated layer can be visualized from 680 to $320 \mathrm{hPa}$. This corresponds to a large ozone enhancement ( $35 \mathrm{ppbv}$ ) which mixing ratio increases up to 95 ppbv. The 13 October 1992 temperature profile is characterized by at least four inversions from 600 to $340 \mathrm{hPa}$. An ozone enhancement corresponds to each inversion, the larger mixing ratio observed ( $95 \mathrm{ppbv}$ ) is localized from 450 to $340 \mathrm{hPa}$. Another ozone enhancement is identified above $300 \mathrm{hPa}$ that reaches 100 and $120 \mathrm{ppbv}$ on the 13 and 6 October 1992, respectively. When regarding at ozone concentration $\left(\mathrm{molec} / \mathrm{cm}^{3}\right)$, the layer localized between 600 and $400 \mathrm{hPa}$ on 6 October 1992, and from $500 \mathrm{hPa}$ to $300 \mathrm{hPa}$ on 13 October 1992 constitutes the ozone maximum for each profile.
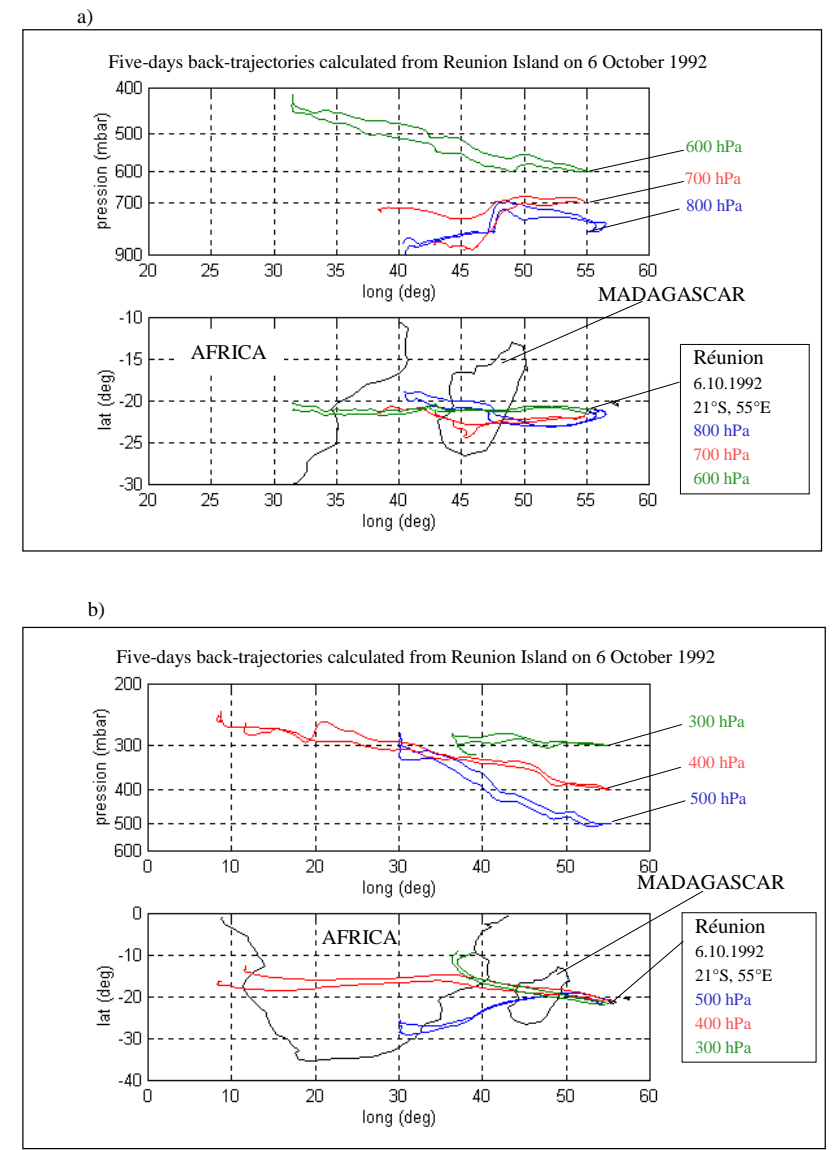

Fig. 4. Five-days backward trajectories ending over Reunion Island the 6 October 1993 for 6 pressure levels. (a) $800 \mathrm{hPa}, 700 \mathrm{hPa}$, and $600 \mathrm{hPa}$. (b) $500 \mathrm{hPa}, 400 \mathrm{hPa}$, and $300 \mathrm{hPa}$. The representation is two 2D projections: longitude-latitude in the lower panel, longitude-pressure in the upper panel.

A detailed back-trajectography study has been performed for each case in order to identify the origin of the observed ozone enhancements. Each profile has been separated in six pressure levels: $800,700,600,500,400$ and $300 \mathrm{hPa}$. The results are shown in Fig. 4 (6 and 5 October (13 October)). A westerly origin from the African continent or Madagascar is identified at all levels for the 6 October 1992, which explains why the troposphere appears rather more homogeneous than on 13 October. Concerning 13 October 1992, the westerly origin from Madagascar or the African continent is present at $700 \mathrm{hPa}, 600 \mathrm{hPa}, 400 \mathrm{hPa}$, and $300 \mathrm{hPa}$. At $500 \mathrm{hPa}$, the air mass origin is southwest, with a very strong subsidence during the transport $(250 \mathrm{hPa}$ between 3 days). Usually, the zonal circulation appears to be from the East, from $800 \mathrm{hPa}$ to $700 \mathrm{hPa}$ during this period (Taupin et al., 1999). When regarding the air mass trajectories performed at $800 \mathrm{hPa}$ (Figs. 4 and 5) in both October 1992 cases, an Easterly origin is definitely observed as the air mass passes over Reunion Island. However, the five-day origin of the air mass appears to become westerly, which signifies 
a)

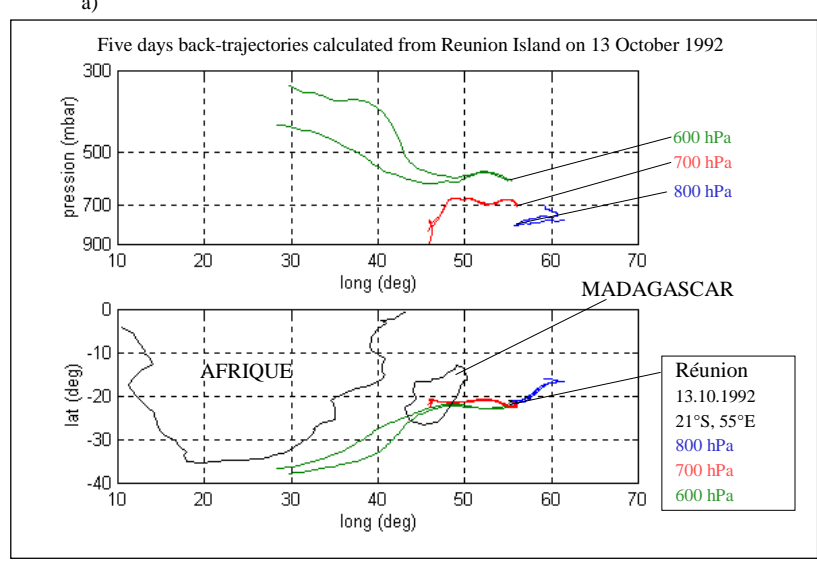

b)

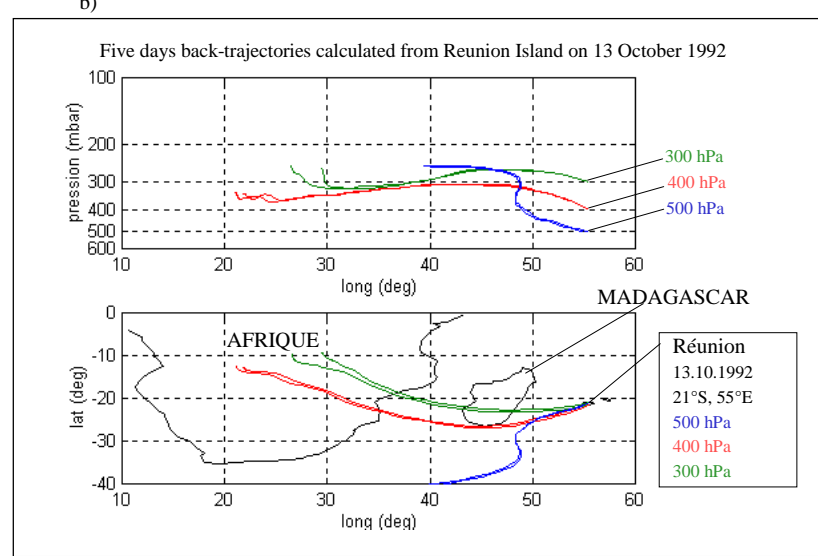

Fig. 5. The same as Fig. 4, but for 13 October 1992.

that a recirculation occurs in the Indian Ocean due to the descending branch of the walker cell. This recirculation allows contamination of the Reunion Island lower troposphere with biomass burning product just above the trade-inversion. One can note the particular $500 \mathrm{hPa}$ back-trajectories calculated for 13 October 1992. Two remarkable points are to be noted concerning this particular case; the southerly origin of the air mass and the strong subsidence during transport $(50 \mathrm{hPa} / \mathrm{day})$. This trajectory corresponds to a thin layer of ozone enhancement on the ozone profile (Fig. 3) and dry air on the relative humidity profile. These features constitute similarities between this trajectory case and those already shown by Baray et al. (1998) and described as stratospheric air intrusions. A tracer study, using potential vorticity, would allow in to classify this ozone enhancement as stratospheric in origin.

Unfortunately, no TRACE-A measurements were available for the days of air mass departure from the African continent. Therefore, the aim of the present study is somewhat limited in the sense that it tends to make a link between the chemical evolution of biomass burning emissions and general features in ozone observations above Reunion Island. However, as previously noted, using the data obtained during this campaign provides a unique constraint on the initial
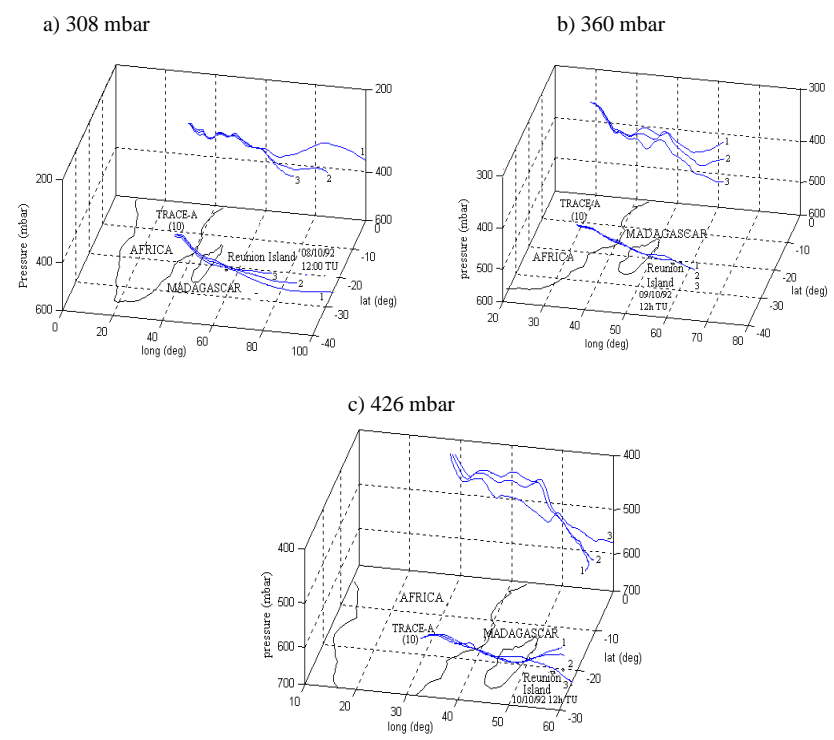

Fig. 6. Forward trajectories calculated from flight 10 of the TRACE-A campaign. The time resolution of computation is $10 \mathrm{~min}$, and use E. C. M.W.F. data. (a) $308 \mathrm{hPa}$, (b) $360 \mathrm{hPa}$, (c) $426 \mathrm{hPa}$. The graph is 3-Dimensionnal: $\mathrm{x}$-axis is latitude, $\mathrm{y}$-axis is longitude, and $\mathrm{z}$-axis is pressure. Two projections of the trajectories have been represented: longitude-pressure and latitude-longitude.

conditions for modelling the ozone formation during transport from the African continent to the Indian Ocean. Consequently, the modelling study will be performed from the TRACE-A campaign toward the Indian Ocean. We will also quantify the ozone production that occurs during the upper tropospheric transport of contaminated air masses and tentatively explain the role of biomass burning in the ozone enhancements observed above Reunion Island.

\subsection{TRACE-A data}

In order to perform this modelling study, we need measurements to initialise the chemical model box near the African biomass burning source regions. Airborne measurements obtained during the TRACE-A campaign will be used for this purpose. In particular, the upper tropospheric air masses sampled during flight 10 were most strongly affected by biomass burning emissions (Fishman et al., 1996b). In order to analyse which of these polluted air masses could possibly be transported to Reunion Island, eight three-to-six day forward trajectories have been calculated starting at flight positions from 800 to $300 \mathrm{hPa}$. These kinetic air mass trajectories are calculated from 3D wind fields provided by the European Centre for Medium-range Weather Forecast (ECMWF) analyses at $6 \mathrm{~h}$ intervals on a $0.75^{\circ}$ grid. The trajectory module delivers, at each time step of $10 \mathrm{~min}$, the instantaneous position, pressure, temperature and humidity to the chemical module (see below). The validity of the trajectory package for its use over the Indian Ocean has been previously demonstrated by Baldy et al. (1996). 

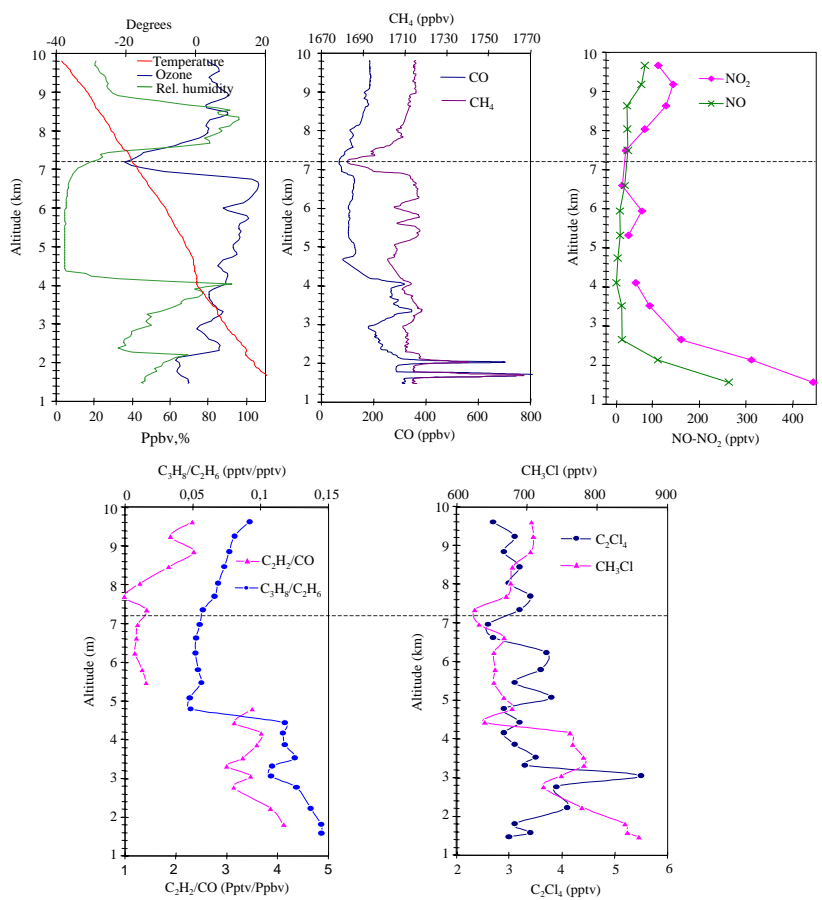

Fig. 7. Chemical data measured during the flight 10 of TRACE-A campaign over a biomass-burning region of Southern Africa. The layer corresponding to the pressure levels $308 \mathrm{hPa}$ and $360 \mathrm{hPa}$ has been delimited $(7-10 \mathrm{~km})$.

Table 1. Trace gas concentrations measured in the layer corresponding to the pressure level $426 \mathrm{hPa}$ and used for the initialisation of the trajectory-chemistry model in this case

\begin{tabular}{lc}
\hline Component & Measured Values \\
\hline Ozone (ppbv) & $78-81$ \\
$\mathrm{NO}_{x}$ (pptv) & $115-122$ \\
$\mathrm{CO}$ (ppbv) & $128-140$ \\
$\mathrm{CH}_{3} \mathrm{Cl}$ (pptv) & 674 \\
$\mathrm{C}_{2} \mathrm{Cl}_{4}$ (pptv) & 4,1 \\
$\mathrm{C}_{3} \mathrm{H}_{8} / \mathrm{C}_{2} \mathrm{H}_{6}$ (pptv/pptv) & 0,07 \\
$\mathrm{C}_{2} \mathrm{H}_{2} / \mathrm{CO}$ (pptv/ppbv) & 1,4 \\
Ethene (pptv) & 5 \\
Ethane (pptv) & 790 \\
$\mathrm{HNO}_{3}$ (pptv) & 1400 \\
\hline
\end{tabular}

From this study forward trajectories have been selected which indeed pass in the free troposphere over Reunion Island some days later (Fig. 6). These trajectories will be used to study the evolution of ozone and its precursors during transport in the free troposphere over the Indian Ocean. The first two trajectories correspond to the second descent of flight 10; they have been extracted from an upper tropospheric layer ranging from 7 to $9 \mathrm{~km}$ and are located at $11^{\circ} \mathrm{S}$, $29 \mathrm{E}$, centred in the vertical around $308 \mathrm{hPa}$ and $360 \mathrm{hPa}$, respectively. The third trajectory corresponds to a longer horizontal flight leg of the aircraft at $426 \mathrm{hPa}$, near $15^{\circ} \mathrm{S}, 28^{\circ} \mathrm{E}$.

The measurements obtained during the second descent of

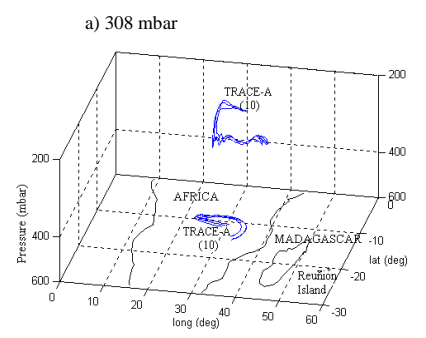

b) $360 \mathrm{mbar}$

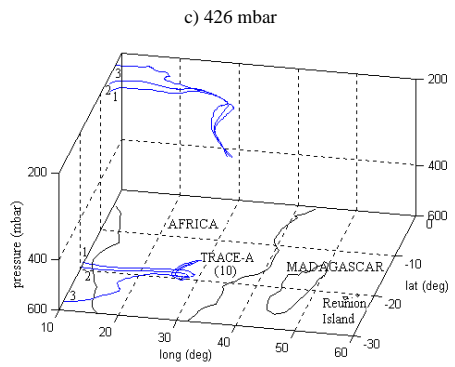

Fig. 8. Same as Fig. 6, but backward instead of forward trajectories.

flight 10 are presented in Fig. 7; the chemical characteristics of the layer centred on the $426 \mathrm{hPa}$ pressure level are shown in Table 1. The ratios $\mathrm{C}_{3} \mathrm{H}_{8} / \mathrm{C}_{2} \mathrm{H}_{6}$ and $\mathrm{C}_{2} \mathrm{H}_{2} / \mathrm{CO}$ have been calculated from the measurements, in order to roughly estimate the age of the air mass relative to a contamination by a pollution event, following a method developed by (Gregory et al., 1996) (relative chemical age).

The relative chemical age of the layers at 308 and $360 \mathrm{hPa}$ is estimated to be 3-5 days (Fig. 7). The layer containing the pressure level $426 \mathrm{hPa}$ has aged by more than 5 days (Table 1). More recent contact with emissions by layers at 308 and $360 \mathrm{hPa}$ also tends to be confirmed by the abundance of ethylene, a short lifetime hydrocarbon whose mixing ratios are equal to $20 \mathrm{pptv}$ at 308 and $360 \mathrm{pptv}$ against $5 \mathrm{pptv}$ at $426 \mathrm{hPa}$ in the third layer. Measured mixing ratios of $\mathrm{CH}_{3} \mathrm{Cl}$ (Fig. 7), a specific tracer for biomass burning (Gregory et al., 1996), show a sensitive increase (from 600 to 670-700 pptv) in all three layers studied as compared to the altitude range located just below (4-6 km), suggesting biomass burning as the origin of the contamination. On the contrary, the mixing ratios of $\mathrm{C}_{2} \mathrm{Cl}_{4}$, a tracer for urban pollution, are always low. Finally, the large relative humidity values recorded from 400 to $300 \mathrm{hPa}$ tend to favour recent contamination by a convective event, that could explain a biomass burning contamination in the upper troposphere.

In addition, to best identify the origin of the air masses studied, we have also calculated four to five day backtrajectory clusters (central trajectory plus four trajectories shifted by $\pm 1^{\circ}$ in longitude and latitude) for all three pressure levels (Fig. 8). The five-day origin of the air mass arriving at $308 \mathrm{hPa}$ is near the East coast of the African continent (Fig. 8a), where biomass burning is very active during this period as shown by Randriambelo et al. (1998) and illustrated on Fig. 9. In addition, these trajectories display strong ascendant motion (pressure decrease by about $100 \mathrm{hPa}$ ) $30 \mathrm{~h}$ before arriving when travelling through a convective region (Fig. 9). 


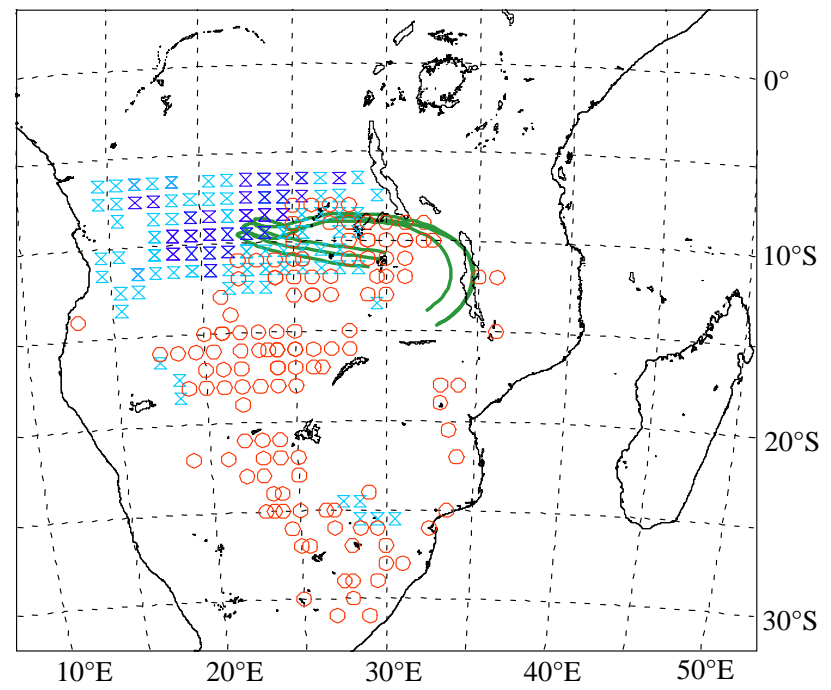

Fig. 9. Map of the southwestern Indian Ocean region, showing TOVS (http://eosdata.gsfc.nasa.gov) cloud top height and precipitations values extracted for the 4 and 5 October 1992. The locations where the cloud top height is higher than $320 \mathrm{mbar}$, and precipitations larger than $7 \mathrm{~mm}$ /day are shown in light blue, locations with cloud top height above $320 \mathrm{hPa}$ and precipitations larger than $15 \mathrm{mmm} /$ days are dark-blue drawn. The locations of intense fires have been added for the 3-4 October period with red circles. The back trajectories cluster, calculated from TRACE-A measurement locations at $308 \mathrm{hPa}$ the 6 October 1992, and described in Fig. 6 is also shown.

This region has also been identified as a strong to deep convection zone (cloud top height from 7-10 km to tropopause) by Thompson et al. (1996) and well schematised by Jacob et al. (1996) using the Walker circulation. Also the air mass at $360 \mathrm{hPa}$ (Fig. 8b) originates over the eastern coast of the African continent.

Thus, from all these arguments (trace gas ratios, biomass burning tracers, fire and convection locations, trajectories), a contamination of the layers at 308 and $360 \mathrm{hPa}$ with African biomass burning emissions seems very probable.

On the contrary, the back trajectory for the third layer $(426 \mathrm{hPa}$, Fig. 5c) indicates an origin of the air mass over the Atlantic Ocean, without contamination during the last five days, that agrees well with a 5 to 6 day relative chemical age. The ozone mixing-ratio is larger than $75 \mathrm{ppbv}$ in all layers; thus significant ozone build-up has already occurred between the time of emission and measurement. However, as $\mathrm{No}_{x}$ mixing ratios mostly exceed $100 \mathrm{pptv}$ and the $\mathrm{CO}$ mixing ratios exceed $100 \mathrm{ppbv}$, further net photochemical ozone formation may be expected to occur over the Indian Ocean.

\section{Meteorological context of the TRACE-A period}

Figure 10 shows the ECMWF analysed wind fields at 1000 and $500 \mathrm{hPa}$ for 6 October 1992, the first day of our trajectory-chemistry study. At the $1000 \mathrm{hPa}$ level, winds

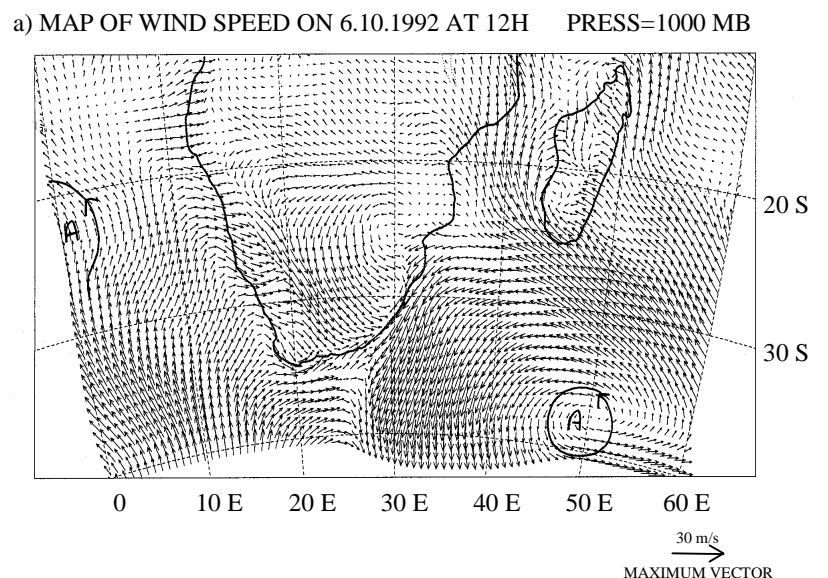

b) MAP OF WIND SPEED ON 6.10.1992 AT 12H PRESS=500 MB

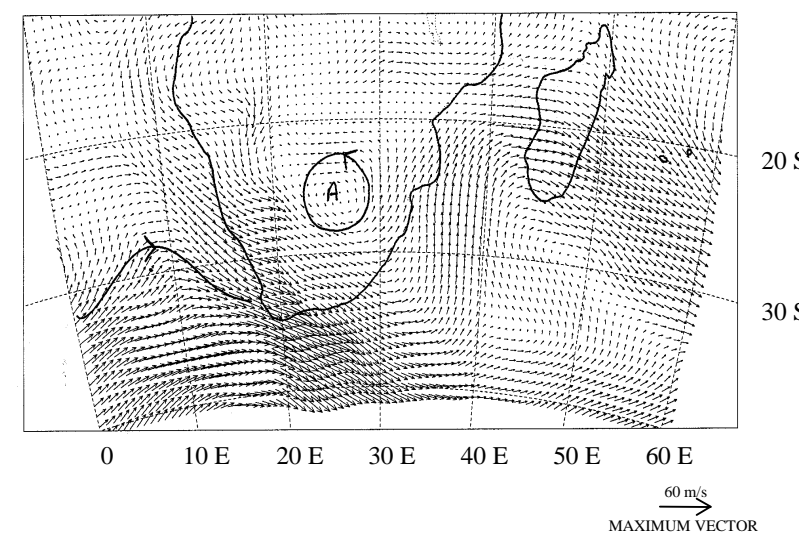

Fig. 10. Meteorological context of the TRACE-A campaign. Horizontal wind on isobaric surfaces on 6 October 1992, at 12:00 T. U., from ECMWF data. a) Surface, b) $500 \mathrm{hPa}$.

are weak and variable over Southern Africa north of $20^{\circ} \mathrm{S}$. South of $20^{\circ} \mathrm{S}$, winds over Southern Africa are confluent and deviated to a southerly direction. The mid-troposphere at 500 mbar (approximately $5.5 \mathrm{~km}$, Fig. 10b) is characterised by the predominance of the westerly flow over the Indian Ocean. At upper levels ( $200 \mathrm{hPa}$, not shown), we note a prevailing zonal flow from West to East in the whole region. The circulation patterns observed on 6 October 1992 are generally representative of the whole TRACE-A period (from 21 September to 27 October 1992) (Bachmeier et al., 1996). This allows us to consider the particular period studied here as rather typical for free tropospheric long-range transport of biomass burning emissions and products.

\section{Model description}

The trajectory-chemistry model used for this work describes the evolution of chemically active species of an air parcel during its transport along a trajectory. It is the free tropospheric version of the trajectory-chemistry model MELCHIOR (ModelE Lagrangien de CHImie de l'Ozone à l'échelle Régionale) developed at Service d'Aéronomie for 
studies in the boundary layer (Lattuati, 1997). The free tropospheric model consists of three parts:

1. the calculation of air mass trajectories,

2. the chemical initialisation of the air parcel, and

3. the calculation of the chemical evolution of the species.

The advantages of the use of a lagrangian model in this study are its simple set-up and the fact that individual air parcels can be studied. This makes the model initialisation straightforward and allows a more direct interpretation of the results as compared to a 3D eulerian model study.

The air mass trajectories used by the lagrangian model are those previously used (Fig. 3) to demonstrate the free tropospheric transport of air masses between the African biomass burning zones and Reunion Island. The gas phase chemical reaction scheme used in the chemistry module describes the chemical behaviour of 77 gaseous species, through about 150 reactions (Lattuati, 1997). This scheme has been extended and updated from an original continental boundary layer chemistry scheme (Hov, 1985). The hydrocarbon degradation scheme is very similar to the EMEP gas phase chemical mechanism (Simpson, 1992) and is a priori adapted as for biomass burning as well for industrial or traffic emissions. Six hydrocarbon species (ethane, butane, ethene, propene, isoprene and o-xylene) represent alkane, alkene, ketones and aromatic compounds. Their oxidation by $\mathrm{OH}, \mathrm{O}_{3}$ and $\mathrm{NO}_{3}$ yields eleven oxygenated compounds, including formaldehyde and higher aldehydes, ketones, bicarbonyls, unsaturated carbonyls and alcohols. Adaptations have been made to allow the simulation of free tropospheric conditions. In particular, pernitrates $\left(\mathrm{HNO}_{4}, \mathrm{CH}_{3} \mathrm{NO}_{4}\right)$ have been added and the pressure dependence of three body reactions has been included (Troe reactions). $\mathrm{RO}_{2}$ and $\mathrm{RO}_{2}$ recombination reactions, which may be important for the degradation of VOC emissions in low $\mathrm{NO}_{x}$ environment, have also been explicitly taken into account. All rate constants have been updated from Atkinson (1994).

Photolysis frequencies $\mathrm{J}$ are calculated using a simple relationship with the zenith angle $\zeta(\mathrm{J}=\mathrm{A} \cdot \exp (-\mathrm{B} / \cos \zeta))$. A and $\mathrm{B}$ factors are taken from a look-up table which has been previously set-up for different altitudes, total ozone columns and cloud cover scenarios (Flatoy et al., 1996) by using the radiative transfer model of Jonson and Isaksen (1993). For this study, a total ozone column of 297 DU is used consistent with measurements from TOMS data and ozone sounding performed at Reunion Island (Taupin, 1998). Cloud free conditions are assumed to prevail during this study, which has been shown from satellite pictures (Fuelberg et al., 1996; Bachmeier et al., 1996).

The air mass trajectories are chemically initialised with aircraft measurements (see also Sect. 3). Measured VOC's, not represented in the gas phase mechanism are replaced by one of the six hydrocarbons and 11 oxygenated hydrocarbons included in the code with the most similar structure and reactivity. In particular, acetone and acetylene measured during

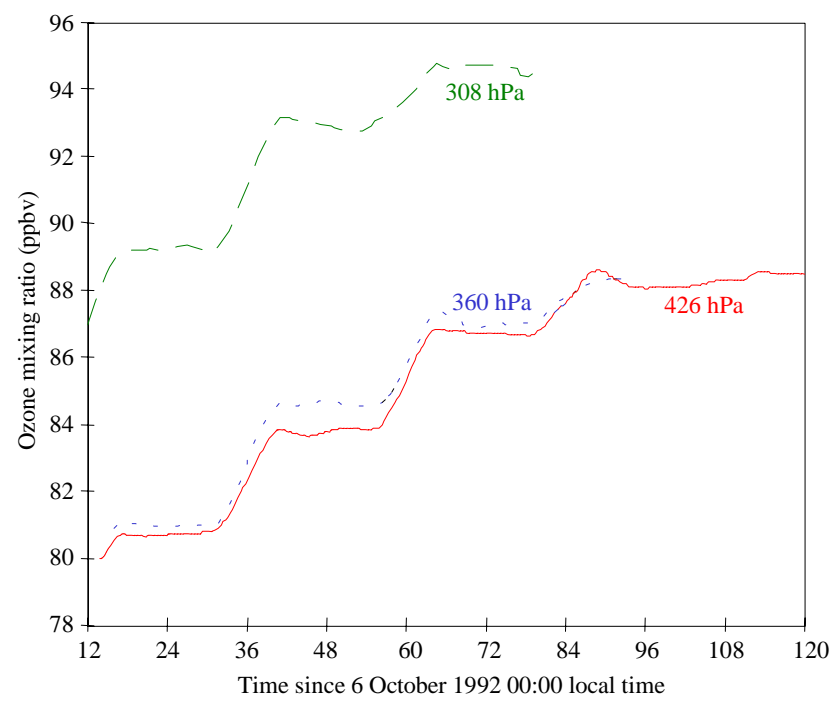

Fig. 11. Ozone generation simulated for 6-10 October 1992, during transport from TRACE-A flight position to Reunion Island.

the TRACE-A campaign are represented by ethane and the propane has been replaced by $n$-butane. The aromatic compounds chemistry (here benzene and toluene) has been represented by the o-xylene chemical scheme. Mass weighting and a reactivity-weighting factor following the procedure of Middleton et al. (1990) is applied. Nevertheless, in Sect. 4.2, it will be shown that the exact knowledge of the NMHC distribution is not critical for the calculation of net ozone production rates.

\section{Results and discussion}

\subsection{Ozone production between Africa and Reunion Island}

The chemical box of the trajectory-chemistry model described in Sect. 3 has been run along the forward trajectories calculated from flight 10 and ending over Reunion Island (Fig. 7). The trajectories keep their homogeneity until they arrive over Reunion Island about three to four days later. In addition, we note a strong subsidence on each calculated trajectory. The trajectory cluster, calculated from $308 \mathrm{hPa}$ over Africa, reaches Reunion Island two and a half days later at $371 \mathrm{hPa}$, with a subsidence rate of $25 \mathrm{hPa} /$ day. The second cluster, starting at $360 \mathrm{hPa}$, arrives over Reunion Island three days later at $471 \mathrm{hPa}$, corresponding to a subsidence rate of $37 \mathrm{hPa} /$ day. The third cluster, calculated from the pressure level $426 \mathrm{hPa}$, reaches Reunion Island 4 days later at $521 \mathrm{hPa}$; the subsidence rate is $24 \mathrm{hPa} /$ day. The subsidence motion indicates that the atmosphere is stratified and that vertical mixing should be weak; hence the lagrangian approach is justified in these cases. When regarding the ozone profile measured at Reunion Island during this period, the ending levels of the trajectories fall in the layer of ozone maximum concentration recorded (not shown). 

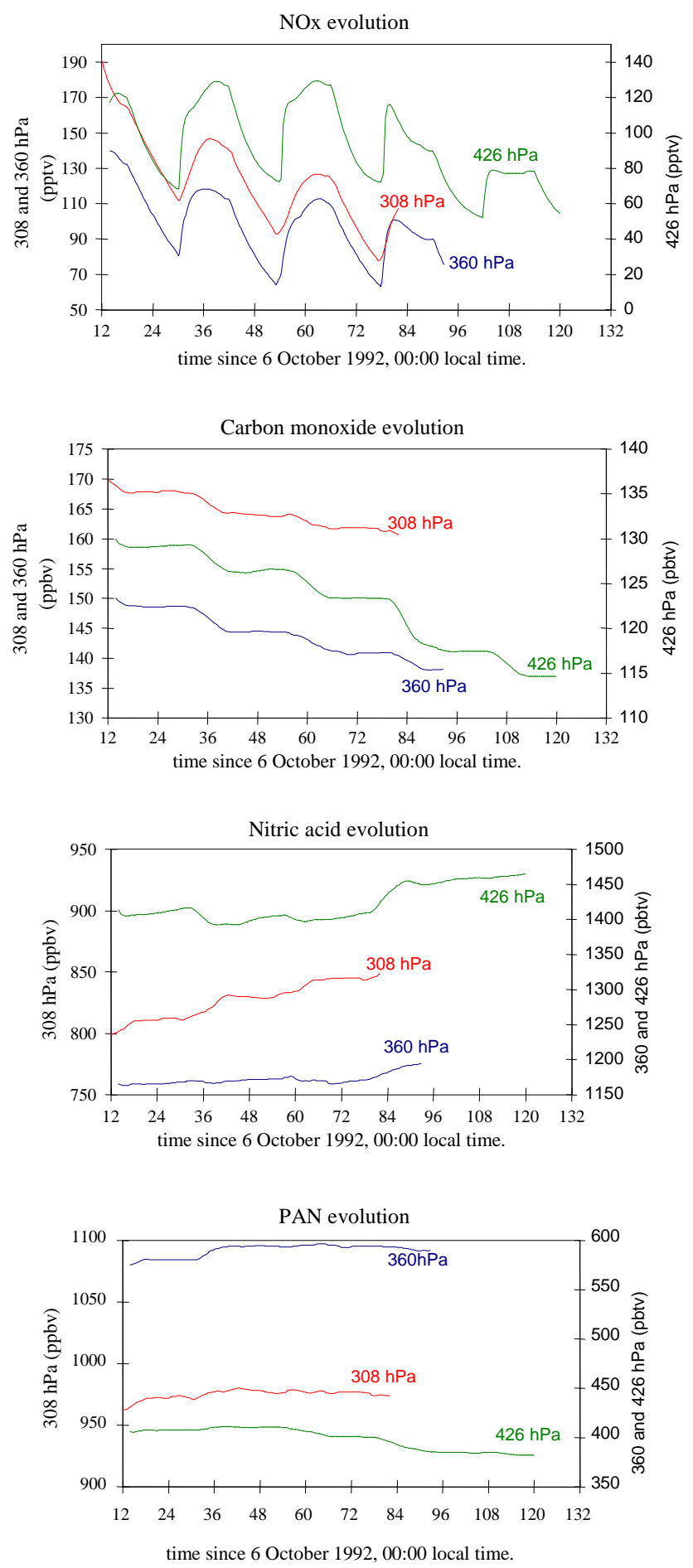

Fig. 12. As Fig. 8 , but for $\mathrm{NO}_{x}, \mathrm{CO}, \mathrm{HNO}_{3}$ and PAN.

The evolution of the ozone mixing-ratio for each trajectory studied is presented in Fig. 11. The main result is that ozone production during transport to Reunion Island, at all pressure levels studied, is still significant, declining from 3$4 \mathrm{ppbv/day}$ for the first day to 1-2 ppbv/day for the subsequent days. On the average, we obtain a net ozone production rate between 2,5 and 3 ppbv/day during transport from the African continent to Reunion Island. This ozone production rate appears to be rather homogeneous, which is explained by the fact that initial concentrations for ozone precursors are comparable (140-190 pptv $\mathrm{NO}_{x}, \sim 2 \mathrm{ppb} \mathrm{NO}_{y}$, $150-170 \mathrm{ppbv} \mathrm{CO}$ ). The sensitivity of ozone production rates with respect to initial conditions will be analysed in more detail in Sect. 5.2.

Also, the chemical evolution of some other important trace gases is similar for the three air masses studied (Fig. 12). $\mathrm{NO}_{x}$ species are consumed during transport and transformed into reservoir species $\mathrm{HNO}_{3}$ and PAN. This corresponds to the largest ozone production on the first day of the simulation and to the lower rates on subsequent days. $\mathrm{NO}_{x}$ concentrations on the third day at noon are, respectively, 110, 95 and $100 \mathrm{pptv}$ for the trajectories starting at 308,360 and $426 \mathrm{hPa}$, which is still enough to support net photochemical ozone production. Conversely, reservoir species $\mathrm{HNO}_{3}$ and PAN slightly increase during the simulation, with the exception of PAN for the trajectory at $426 \mathrm{hPa}$. The carbon monoxide net destruction varies between 3 ppbv/day and 6 ppbv/day which implies that, roughly, between half (for trajectories starting at $308 \mathrm{hPa}$ and at $426 \mathrm{hPa}$ ) and one ozone molecule (trajectory 2) are formed per one $\mathrm{CO}$ molecule consumed.

We now compare the ozone production rates obtained in our study with other studies. From observations of the ozone content integrated between 1.5 and $7 \mathrm{~km}$, Gregory et al. (1996) studied the effects of ageing as African air moves off the West African coast over the Atlantic Ocean. By comparing two measured profiles separated by two days of transport, these authors derive a net photochemical ozone production of $6 \mathrm{ppbv} / \mathrm{d}$ during transport. Differences with our lower value may be attributed to four reasons,

1. the different region considered (South Atlantic basin vs. Indian ocean,

2. the lower height range in the Gregory et al. 1996 study (1.5-7 km compared to about 5-9 km in our study),

3. the uncertainty inherent in ozone production rates from small differences between ozone profiles, and

4. the uncertainty in the same estimations from photochemical models (see discussion in Sect. 5.3).

By means of a photochemical model (Jacob et al., 1996) have conducted simulations of the instantaneous net ozone production, scaled to a diurnal average, using all measurements performed during the TRACE-A period. This approach is similar to ours but note that our net ozone production rates are calculated by taking into account the decline of ozone precursors and in particular $\mathrm{NO}_{x}$ during the days after the measurements, whereas Jacob et al. (1996) assumed the $\mathrm{O}_{3}$ precursors to the constant, except NO, over the calculation period. Near source regions of emission, over the Southern African continent and near its eastern coast Jacob et al. (1996) estimate for the 8 to $12 \mathrm{~km}$ range a net ozone production per day between 1 to about $18 \mathrm{ppbv}$, with most of the values around 2-4 ppbv/day. Over the South Atlantic 
Table 2. Sensitivity of ozone production to modifications in the initial concentrations of some important compounds for the chemical trajectory starting at $308 \mathrm{hPa}$. Results are presented as percentage change with respect to the net ozone production obtained in the reference case

\begin{tabular}{lcc}
\hline $\begin{array}{l}\text { Initial concentration } \\
\text { changes }\end{array}$ & $\begin{array}{c}\text { \% Change on ozone } \\
\text { production }\end{array}$ \\
\hline NMHCs & $+30 \%$ & -2.6 \\
& $-30 \%$ & +2.1 \\
$\mathrm{CO}$ & $+30 \%$ & +7.5 \\
& $-30 \%$ & -9.5 \\
$\mathrm{NO}_{x}$ & $+30 \%$ & +17.2 \\
& $-30 \%$ & -20.7 \\
$\mathrm{HNO}_{3}$ & $+30 \%$ & +8.2 \\
& $-30 \%$ & -8.7 \\
$\mathrm{H}_{2} \mathrm{O}$ & $+30 \%$ & +1.6 \\
& $-30 \%$ & -2.6 \\
\hline
\end{tabular}

basin, that is several days of transport away from the probable source regions, they still estimate a net photochemical ozone production of $2.1 \mathrm{ppb} /$ day in the $8-12 \mathrm{~km}$ range and less than $2 \mathrm{ppbv} / \mathrm{day}$ in the $4-8 \mathrm{~km}$ range. These values are similar to our estimations in the 5-9 km altitude range of about 2.5-3 ppbv/day on the first day (near source regions) and 1-2 ppbv/day after several days of transport. This means that photochemical ozone production over the Indian ocean is probably of the same order of magnitude of as that calculated over the south Atlantic basin.

\subsection{Influence of initial concentrations on ozone production}

In this section, we study the sensibility of net ozone production with respect to initial concentrations of several species in order to study the chemical regime of the biomass burning plume and also to encounter the effect of the uncertainty inherent in the initial conditions employed. For example, real NMHC's are represented by model species sometimes with different reaction paths (for example acetylene and acetone represented by ethane). Moreover, $\mathrm{NO}_{2}$ concentrations measured during the TRACE-A campaign have been estimated to be rather uncertain (Jacob et al., 1996). Finally, nitric acid measurements are sparse (2-15 min time resolution compared to 3 min for NO) (Jacob et al., 1996); so each measured data corresponds to a larger altitude range than considered for the initialisation of each air parcel. In order to study the sensitivity of ozone production, with respect to these compounds and also to other chemically important species such as $\mathrm{CO}$ and water vapour, we have applied a $30 \%$ variation to the initial concentrations for the trajectory at $308 \mathrm{hPa}$. The $30 \%$ value is not meant to represent the uncertainty of any of these initial concentrations; it is merely chosen to provide a common basis for the comparison of the sensitivities.

The results summarised in Table 2 indicate the strongest sensitivity of $\mathrm{NO}_{x}$ initial concentrations. Indeed, ozone production is basically $\mathrm{NO}_{x}$ limited. Also, the sensitivity of nitric acid initial concentration is important as $\mathrm{HNO}_{3}$ photolysis is an important pathway for $\mathrm{NO}_{x}$ recycling. $\mathrm{CO}$ is important also as it transforms $\mathrm{OH}$ into $\mathrm{HO}_{2}$, which reduces removal of $\mathrm{NO}_{x}$ by $\mathrm{OH}$. On the other hand, water vapour concentrations are not very sensitive; apparently the availability of $\mathrm{OH}$ and subsequently $\mathrm{HO}_{2}$ and $\mathrm{RO}_{2}$ radicals from the reaction of $\mathrm{O}\left({ }^{1} \mathrm{D}\right)$ with water vapour does not much effect the net ozone production. Surprisingly, the sensitivity of NMHC initial concentrations is slightly negative. The reason for this is that, first, the largest contribution to $\mathrm{OH}$ to $\mathrm{HO}_{2}$ conversions stems from $\mathrm{CO}$ and, second, an increase in NMHC's favours PAN formation which consumes $\mathrm{NO}_{x}$ and thus decreases ozone production.

This study suggests that the strongest uncertainty on the calculated net ozone production rate probably stems from the uncertainty in $\mathrm{NO}_{x}$ measurements. Indeed, some disagreements have been found between measured and simulated $\mathrm{NO}_{2} / \mathrm{NO}$ ratios (Smyth et al., 1996) that we have also observed. Moreover, the determination of $\mathrm{NO}_{2}$ was often at or below the instrument's limit of detection during the TRACE A campaign and may include contributions from $\mathrm{HO}_{2} \mathrm{NO}_{2}$ or $\mathrm{N}_{2} \mathrm{O}_{5}$ (Smyth et al., 1996; Sandholm et al., 1994). Since we have used the measured $\mathrm{NO}_{x}$ values $\left(\mathrm{NO}+\mathrm{NO}_{2}\right)$, we will consider them as an upper limit.

\subsection{Larger scale relevance of the results}

We will now briefly discuss the representativity and the larger scale importance of our results. To this purpose, and as it represents the layer with the largest ozone production among the studied cases ( 3 ppbv/day), we have compared the initial concentrations used for the trajectory starting at $308 \mathrm{hPa}$ with average mixing ratios measured during the TRACE-A flight 10 at similar altitudes. This layer around $308 \mathrm{hPa}$ is one of the most polluted sampled at this altitude and during this flight (see Table 3). In addition, as previously discussed, the measured $\mathrm{NO}_{x}$ concentrations have to be considered as upper limits. Thus, our value of a 2.5-3 ppbv/day net ozone production probably represents an upper limit for more average conditions over the Western Indian Ocean during October.

Also, we may ask, what will be the chemical evolution of the air mass when transported further westward from Reunion Island, over the Indian Ocean. A longer-term simulation of the layer at $308 \mathrm{hPa}$ (not shown) shows that, on day 6 , the $\mathrm{NO}_{x}$ mixing ratio approaches its steady state concentration where loss reactions are balanced by a supply of fresh $\mathrm{NO}_{x}$ from reservoir species $\mathrm{HNO}_{3}$ and PAN. This corresponds to daily maximum $\mathrm{NO}$ concentrations of about 30 pptv, allowing no further net ozone production but preventing ozone loss. The maps of tropospheric ozone content derived from satellite analyses presented by Fishman et al. (1996a), show that the maximum of ozone increase is reached not far eastward from Reunion Island, as predicted by our study. The satellite analysis also shows a large eastward extension of the plume (at least to $60^{\circ} \mathrm{E}$, the limit of the analysed domain), again in line with our finding of a 
Table 3. Main mixing ratios measured during flight 10 of the TRACE-A campaign around the 308 hPa pressure level, as compared with the initial mixing ratios used to initialise the same level simulation

\begin{tabular}{lccc}
\hline & \multirow{2}{*}{$\begin{array}{c}\text { Modelled initial } \\
\text { Species }\end{array}$} & \multicolumn{2}{c}{ Flight 10 Measurements } \\
\cline { 3 - 4 } & mixing ratios & Min-max & Number of soundings \\
\hline $\mathrm{NO}_{x}$ & $191 \mathrm{pptv}$ & $84-210 \mathrm{pptv}$ & 18 \\
$\mathrm{HNO}_{3}$ & $800 \mathrm{pptv}$ & $689-1256 \mathrm{pptv}$ & 3 \\
$\mathrm{PAN}$ & $963 \mathrm{pptv}$ & $594-963 \mathrm{pptv}$ & 3 \\
$\mathrm{Ozone}$ & $87 \mathrm{ppbv}$ & $80-90 \mathrm{ppbv}$ & 70 \\
$\mathrm{CO}$ & $170 \mathrm{ppbv}$ & $68-79 \mathrm{ppbv}$ & 100 \\
$\mathrm{CH}$ & $1713 \mathrm{ppbv}$ & $1623-1723 \mathrm{ppbv}$ & 100 \\
$\mathrm{NMHCs}$ & $1537 \mathrm{pptv}$ & $458-1609 \mathrm{pptv}$ & 15 \\
\hline
\end{tabular}

near zero photochemical ozone balance after about a week of transport and thus a very large lifetime of ozone in the upper troposphere over the Indian ocean.

At this stage of plume ageing, and in the absence of a fresh supply of $\mathrm{NO}_{x}$ sources, for example, from lightning (Smyth et al., 1996), it is the dilution or heterogeneous removal of the $\mathrm{NO}_{x}$ reservoir species which will ultimately drive the lifetime of the large ozone burden produced from biomass burning emissions and its impact on the global tropospheric ozone budget. After several days of transport, the hypothesis of no mixing of the air parcels made for these calculations becomes more and more questionable. However some hypotheses can be driven that are linked to the walker cell circulation:

As the air subsides over the Indian Ocean (Fig. 6), net ozone loss can take place in the lower troposphere. The air masses then reach the Easterly circulation (descending branch of the walker cell) and bring residual ozone produced from biomass burning emissions in Reunion Island lower troposphere, just above the trade-inversion (Fig. 3). This hypothesis can be corroborated with the presence of two ozone concentration (when converting the mixing ratio into molec/ $\mathrm{cm}_{3}$ ) maxima located just above the zonal wind inversion for the larger one, and between the trade-inversion and the zonal inversion for the second one.

In view of the current findings, one can wonder what is then the role of biomass burning on tropospheric ozone concentration over Reunion Island as compared with stratospheric intrusion. Ozone produced from biomass burning emissions is displayed in the whole troposphere above the trade-inversion over Reunion Island from August to December. Stratospheric intrusions occur at different altitudes over Reunion Island by way of tropopause breaks due to the westerly Jet-stream (Baray et al., 1998) during winter, and near zones of deep convection during summertime (Baray et al., 1999). These events are very strong (up to $200 \mathrm{ppbv}$ of ozone) but time limited (few days); ozone decrease takes place rapidly due to low $\mathrm{NO}_{x}$ mixing ratios conditions, and to subsidence. At present, biomass burning constitutes the main source of ozone in the Mid to upper-troposphere of Reunion island.

We can also compare the contamination that occurs over the Indian Ocean with the contamination of the South Atlantic basin. Even if the production rates of ozone in the free troposphere are comparable, the tropospheric ozone content appears to be larger above Ascension Island, for example (Fishman et al., 1996). Indeed, the Atlantic basin troposphere is contaminated by both the American continent and the African continent. The Indian Ocean free troposphere is primarily contaminated by the African continent and secondarily by Madagascar; the lower troposphere, above the trade-inversion at Reunion Island, also appears to be contaminated due to the recirculation of the upper troposphere air masses over the Indian Ocean due to the descending branch of the Walker cell; this does not constitute a fresh source of biomass burning products.

\section{Conclusion}

This paper presents a case study of ozone production over the Indian Ocean during the African biomass-burning period. To this purpose, we use a trajectory-chemistry model driven by ECMWF analyses and initialised by TRACE-A data. We show that the net upper tropospheric ozone production between the Southern African East coast and Reunion Island is about 2.5-3 ppbv/day for the three trajectories studied which corresponded to the most polluted upper tropospheric layers of TRACE-A flight 10. Our result also falls in the range of values calculated by Jacob et al. (1996) from all TRACE A data between 4 and $12 \mathrm{~km}$, although Jacob et al. (1996) calculate net ozone production rates with fixed precursor concentrations whereas our study allows for decay of precursors. Indeed, our study has shown that a 30\% difference in the initial NMHC concentrations does not sensibly change the averaged net ozone production rate. Consequently, this sensitivity study, with varying initial concentrations, reveals that our calculated net ozone production is most sensitive to the uncertainty in $\mathrm{NO}_{x}$ concentrations used for initialisation and also to $\mathrm{HNO}_{3}$, supplying fresh $\mathrm{NO}_{x}$ and $\mathrm{CO}$, but is only a little sensitive to NMHC initial concentrations and to water vapour. This result shows that the Reunion Island free troposphere (higher than $3 \mathrm{~km}$ ) is mostly contaminated by ozone produced near emission sources (Cook-then-Mix), with little enhancement during transport (less than 10\%). Our results 
also explain the maximum in the ozone plume observed from satellite data near Reunion Island (Fishman et al., 1996a) and its large eastward extension over the Indian Ocean. However, several factors are simultaneously needed that contribute to the ozone enhancement observed over Reunion Island: High ozone concentrations observed in the troposphere over Reunion Island are primarily due to biomass burning that occurs on the African continent and Madagascar. The intensity of the ozone peaks observed depends on the intensity of the fires and of the deep convection occurring not far from the source zones. The variability of the ozone mixing ratios with altitude depends on the zonal circulation, i.e. the westerlies in the free troposphere (higher than $5 \mathrm{~km}$ ), and the presence of recirculation on the Indian Ocean with the descending branch of the walker cell.

Acknowledgement. We wish to thank Y. Pointin, and A. M. Lanquette (LaMP, Clermont-Ferrand, France) for supplying the analysis software of ECMWF data, as well as the TRACE-A Science Team for providing access to the data obtained during the GTE TRACE-a Field Mission on a data archive (http://www-gte.larc.nasa.gov).

Topical Editor D. Murtagh thanks two referees for their help in evaluating this paper.

\section{References}

Atkinson, R.: Gas phase tropospheric chemistry of organic compounds, J. Phys. Chem. Ref. Data, Monograph 2, 1994.

Bachmeier, A. S. and Fuelberg, H. E.: A meteorological overview of the TRACE-A period, J. Geophys. Res., 101 (D19), 23881 23 888, 1996.

Baldy, S., Ancellet, G., Bessafi, M., Badr A., and Lan-Sun-Luk, J. D.: Field observations of the vertical distribution of tropospheric ozone at the island of Reunion (southern tropics), J. Geophys. Res., 101 (D19), 23 835-23 850, 1996.

Baray, J. L., Ancellet, G., Taupin, F. G., Bessafi, M., Baldy, S., and Keckhut, P.: Subtropical tropopause break as a possible stratospheric source of ozone in the tropical troposphere, J. Atm. Sol.Terrestr. Phys., 60 (1), 27-36, 1998.

Baray, J. L., Ancellet, G., Randriambelo T., and Baldy,S.: Tropical cyclone Marlene and stratosphere-troposphere exchange, J. Geophys. Res., 104 (D11), 13 953-13 970, 1999.

Diab, R. D., Jury, M. R., Combrink, J. M., and Sokolic, F.: A comparison of anticyclone and trough influences on the vertical distribution of ozone and meteorological conditions during SAFARI-92, J. Geophys. Res., 101 (D19), 23 809-23 822, 1996.

Fishman, J., Brackett, V. G., Browell E. V., and Grant, W. B.: Tropospheric ozone derived from TOMS/SBUV measurements during TRACE-A, J. Geophys. Res., 101 (D19), 24 069-24.082, $1996 \mathrm{a}$.

Fishman, J., Hoell, Jr., J. M., Bendura, R. D., Mc Neal, R. J., and Kirchhoff, V. W. J. H.: NASA GTE TRACE A Experiment (September-October 1992): Overview, J. Geophys. Res., 101 (D19), 23 865-23 880, 1996b.

Flatoy, F., Hov, O., and Smit H. G. J.: Three dimensional model studies of exchange processes of ozone in the troposphere over Europe, J. Geophys. Res., 100 (D6), 11 465-11 481, 1995.

Fuelberg, H. E., Loring, Jr., R. O., Watson, M. V., Sinha, M. C., Pickering, K. E., Thompson, A. M., Sachse, G. W., Blake, D. R., and Schoerberl, M. R.: TRACE A trajectory intercomparison, 2, Isentropic and kinematic methods, J. Geophys. Res., 101 (D19), 23 927-23 940, 1996.

Garstang, M., Tyson, P. D., Swap, R., Edwards, M., Kållberg, P., and Lindesay, J. A.: Horizontal and vertical transport of air over southern Africa, J. Geophys. Res., 101 (D19), 23 721-23 736, 1996.

Gregory, G. L., Fuelberg, H. E., Longmore, S. F., Anderson, B. E., Collins, J. E., and Blake, D. R.: Chemical characteristics of tropospheric air over the tropical south Atlantic Ocean: Relationship to trajectory history, J. Geophys. Res., 101 (D19), 23957 $23972,1996$.

Hov, O., Stordal, F., and Eliassen, A.: Photochemical oxidant control strategies in Europe: A 19 days case study using a lagrangian model with chemistry, NILU TR5/95, 1985.

Jacob, D. J., et al.: Origin of ozone and $\mathrm{NO}_{x}$ in the tropical troposphere: a photochemical analysis of aircraft observations over the southern Atlantic Basin, J. Geophys. Res., 101 (D19), 24 235-24 250, 1996.

Jonson, J. E. and Isaksen, I. S. A.: Tropospheric ozone chemistry. The impact of cloud chemistry, J. Atmos. Chem., 16, 99-122, 1993.

Lattuati, M.: Impact des émissions europeennes sur le bilan de l'ozone troposphérique à l'interface de l'Europe et de l'Atlantique Nord: apport de la modélisation lagrangienne et des mesures en altitude, Ph. D. thesis, Univ. of Paris VI, 1997.

Middleton, P., Stockwell, W. R., and Carter, W. P. L.: Aggregation and analysis of volatile organic compounds emissions for regional modelling, Atmos. Envir., 24a (5), 1107-1133, 1990.

Randriambelo, T., Baldy, S., Bessafi, M., and Despinoy, M.: An improved detection and characterization of active fires and smoke plumes in southeastern Africa and Madagascar, Int. J. Rem. Sens., 19 (14), 2623-2638, 1998.

Randriambelo, T., Baray, J.-L., and Baldy, S.: Effect of biomass burning, convective venting, and transport on tropospheric ozone over the Indian Ocean: Reunion Island field observations, J. Geophys. Res., 105 (D9), 11 813-11 832, 2000.

Sandholm, S., et al.: Summertime partitioning and budget of NOy compounds in the troposphere over Alaska and Canada: ABLE 3B, J. Geophys. Res., 99, 16 841, 1837-1861, 1994

Simpson, D.: Long period modeling of photochemical oxidants in Europe. Model calculations for July 1985, Atmos. Envir., 25 , 1609-1634, 1992.

Smyth, S. B., et al.: Factors influencing the upper tropospheric distribution of reactive nitrogen over South Atlantic during the TRACE-A experiment, J. Geophys. Res., 101 (D19), 24165 24 186, 1996.

Taupin, F. G.: Analyse et modélisation de la variabilité de l'ozone troposphérique en zone tropicale - Influence du brûlage de biomasse, Ph. D. thesis, Univ. of Clermont-Ferrand, 1998.

Taupin F. G., Bessafi, M., Baldy, S., and Bremaud, P. J.: Tropospheric ozone above southwestern Indian ocean is strongly linked to dynamical conditions prevailing in the tropics, J. Geophys. Res., 104 (D7), 8057-8066, 1999.

Thompson, A. M., Pickering, K. E., McNamara, D. P., Schoeberl, M. R., Hudson, R. D., Kim, J. H., Browell, E. V., Kirchhof, V. W. J. H., and Nganga, D.: Where did tropospheric ozone over southern Africa come from in October 1992? Insights from TOMS, GTE TRACE A and SAFARI 1992. J. Geophys. Res., 101 (D19), 24 251-24 278, 1996. 